\title{
RESEARCH PAPER \\ An evaluation of orange and clear traps with pear ester to monitor codling moth (Lepidoptera: Tortricidae) in apple orchards
}

\author{
Wilson Barros-Parada ${ }^{1}$, Alan L. Knight ${ }^{2}$, Esteban Basoalto ${ }^{3}$, and Eduardo \\ Fuentes-Contreras ${ }^{1}$ \\ 'Facultad de Ciencias Agrarias, Universidad de Talca. Casilla 747, Talca, Chile. \\ ${ }^{2}$ Yakima Agricultural Research Laboratory, USDA-ARS, 5230 Konnowac Pass Road, Wapato, WA 98951, USA. \\ ${ }^{3}$ Southern Oregon Research \& Extension Center, Oregon State University, 569 Hanley Rd, Central Point, \\ OR, 97502, USA.
}

\begin{abstract}
W. Barros-Parada, A.L. Knight, E. Basoalto, and E. Fuentes-Contreras. 2013. An evaluation of orange and clear traps with pear ester to monitor codling moth (Lepidoptera: Tortricidae) in apple orchards. Cien. Inv. Agr. 40(2):307-315. Studies were conducted to evaluate the use of several trap-lure combinations to improve the monitoring of codling moth, Cydia pomonella (L.) (Lepidoptera: Tortricidae), in apple, Malus domestica Bordk. The treatments involved the use of clear, orange, and white traps baited with one or more of the following attractants: the major sex pheromone component of the codling moth, $(E, E)$-8,10-dodecadien-1-ol (codlemone, $\mathrm{PH}$ ); a primary volatile constituent of ripe pear, ethyl $(E, Z)$-2,4-decadienoate (pear ester, PE); and acetic acid (AA). The studies were conducted in an orchard treated with sex pheromone dispensers in Washington State (USA) and in four untreated orchards in the Maule Region (Chile). In Washington State, the PE + AA lures caught more females than the $\mathrm{PE}+\mathrm{PH}$ lure in both the clear and orange traps. The clear traps caught more female moths than the orange traps when each trap was baited with the PE+PH lure. The two lures caught similar total numbers of moths across trap colors. The clear traps baited with $\mathrm{PE}+\mathrm{PH}$ caught significantly more total moths than the orange traps baited with $\mathrm{PE}+\mathrm{AA}$. In Chile, the clear traps baited with $\mathrm{PE}+\mathrm{AA}$ caught more females than the orange traps baited with $\mathrm{PE}+\mathrm{PH}$ over both moth flights during two field seasons. The white traps baited with $\mathrm{PH}$ and the orange traps baited with $\mathrm{PE}+\mathrm{PH}$ caught similar total numbers of moths in three of the four flight periods. The clear trap baited with PE+AA caught significantly fewer moths than the two treatments that included a PH lure in two of the four flight periods. These data suggest that the adoption of clear delta traps with PE+AA lures would allow growers to better track the seasonal population dynamics of female codling moths.
\end{abstract}

Key words: Codlemone, Cydia pomonella, lure, monitoring, pear ester, semiochemical.

\section{Introduction}

Codling moth, Cydia pomonella (L.) (Lepidoptera: Tortricidae) is the most significant pest in apple,

Received May 15, 2012. Accepted October 10, 2012.

Corresponding author:wbarros@utalca.cl pear, and walnut cultivation worldwide (Barnes, 1991). Strict quarantine requirements for certain markets and the establishment of variable minimum residue limits (MRLs) among countries represent a challenge for pome fruit growers, who must maintain a very high level of pest control without overreliance on insecticides. The implementation 
of these integrated programs now generally relies on the combined use of sex pheromone for mating disruption (MD), an intensive monitoring program with the establishment of action thresholds, and the cautious use of supplemental insecticide sprays (Witzgall et al., 2008). Growers' monitoring programs have two primary objectives - to track the seasonal phenology of the pest to better target sprays against the most susceptible life stages and to establish whether local population densities require the use of additional management tactics (Knight and Light, 2005a; b). The major sex pheromone component of codling moth, $(E$, $E)$-8,10-dodecadien-1-ol (codlemone), has been widely used in a variety of traps over the past 40 years (Vickers and Rothschild, 1991). Following a rapid adoption of sex pheromone MD by growers in many major production regions worldwide over the past 15 years, accurate monitoring has become even more important to develop effective integrated programs (Witzgall et al., 2008). Growers adopting MD have typically increased their density of trap use and implemented standardized protocols and new action thresholds (Knight, 2007a). The use of orange traps rather than white traps can increase male captures and minimize the catch of nontargets, such as hymenopterans (Knight and Milczky, 2003, Knight and Fisher, 2006). The identification of ( $E, Z$ )-2,4-ethyl-decadienoate (pear ester) as a potent attractant for both sexes of codling moth has furnished a new opportunity for growers to develop monitoring programs based on female moth catches (Light et al., 2001). The use of pear ester (PE) lures has been found to improve the estimation of both egg hatch timing and local pest population density (Knight and Light, 2005a; b). The use of a combo lure loaded with both codlemone (PH) and PE has become a standard method for MD orchards in many fruit-growing regions (Knight et al., 2005). The site-specific precision management of codling moth has been developed using PE lures and action thresholds for both female and total moth catches (Knight et al., 2009).

Further refinements over the past few years have continued to improve growers' ability to monitor codling moth. The use of clear traps has been found to increase the catch of female moths with PE lures (Knight, 2010a). The addition of acetic acid (AA) with PE has been shown to synergize the catch of both sexes (Landolt et al., 2007). The combined use of a clear trap baited with PE and AA lures has allowed growers to catch the greatest numbers of female codling moth (Knight, 2010b). A number of plant volatiles other than PE have been tested, but only the use of $(E)$-4,8-dimethyl1,3,7-nonatriene (DMNT) with AA has shown some effectiveness in catching female codling moth (Knight et al., 2011).

Interestingly, the effectiveness of using PE to monitor both sexes of codling moth has been reported to vary among geographical regions: Italy (Ioriatti et al., 2003; De Cristofaro et al., 2004), Australia (Il'ìchev, 2004; Thwaite et al., 2004), Bulgaria (Kutinokova et al., 2005), USA (Knight and Light, 2005c), Canada (Trimble and El-Sayed, 2005), New Zealand (Mitchell et al., 2008), and Argentina (Fernández et al., 2010). Many of these authors have reported low catches of females with PE lures used either alone or in combination with PH. This variation may be due to experimental differences among researchers in terms of trap design and placement, seasonality, crop, cultivar, and the relative importance of immigrant versus within-field moths (Knight and Light, 2005d). Differences in the responses of geographically distinct codling moth populations to PE may also be due to genetic differences and insecticide resistance status (Sauphanor et al., 2007). Clearly, it is important to test new trap-lure combinations in each fruit production region for several years prior to grower adoption. To date, the use of orange or clear traps baited with PE lures has not been reported outside the USA.

In this study, we report on a series of experiments conducted in Washington State (USA) and in the Maule Region (Chile) to further investigate the development of an optimal trap-lure combination to increase the catch of codling moth and, in particular, the numbers of female moths. Clear 
and orange delta traps baited with either $\mathrm{PE}+\mathrm{AA}$ or $\mathrm{PE}+\mathrm{PH}$ were compared in a two-week trial in Washington State. More extensive trials were run in four orchards over two four-month field seasons in Chile. Two standard trap-lure combinations, namely, a white trap baited with $\mathrm{PH}$ and an orange trap baited with $\mathrm{PE}+\mathrm{PH}$, were compared with a clear delta trap baited with $\mathrm{PE}+\mathrm{AA}$ in these tests. Lastly, it is worth mentioning that the Washington experiment was not replicated in different orchards; hence, a comparison between countries was not intended.

\section{Materials and methods}

\section{Traps and lures}

Clear delta traps were constructed in the laboratory from rolls of semirigid UV-stabilized plastic film (0.25 mm thickness; W. J. Dennis Co., Elgin, IL, USA). Pieces of plastic were cut and folded to approximately the same size $(27 \times 20 \times 11 \mathrm{~cm})$ as the commercial white and orange delta traps used in our studies (Pherocon VI, Trécé Inc., Adair, OK, USA). The trap openings were $72 \mathrm{~cm}^{2}$. Trap liners $\left(340 \mathrm{~cm}^{2}\right)$ were also made from the clear plastic and coated with $10.0 \mathrm{~g}$ Tangle-trap adhesive (The Tanglefoot Co., Grand Rapids, MI, USA). An orange $7.0 \times 11.0 \mathrm{~cm}$ shield constructed from orange delta traps was stapled at the center of the top ridge of the trap to provide $\mathrm{UV}$ protection for the lure. A $15 \mathrm{~cm}$ piece of $1.4 \mathrm{~cm}$ wide yellow tie strapping (Postal Products Unlimited, Milwaukee, WI, USA) was laced through slits made in both the trap and shield and attached to a U-shaped neon orange plastic clip $(4.0 \times 5.5 \mathrm{~cm})$. Smaller white diamond traps $(17.5 \times 16.5 \times 11 \mathrm{~cm})$ were used during the 2009-2010 season (Pherocon IIB, Trécé Inc., Adair, OK, USA). These traps had a smaller opening $\left(37 \mathrm{~cm}^{2}\right)$ than the delta traps and were coated with adhesive on all interior surfaces, a total of $522 \mathrm{~cm}^{2}$.

Four lures were used in these trials, including three commercial septa provided by Trécé Inc.
(Salinas, CA, USA). Pherocon DA (PE) was loaded with $3 \mathrm{mg}$ of pear ester. Pherocon CM$\mathrm{DA}(\mathrm{PE}+\mathrm{PH})$ was loaded with $3 \mathrm{mg}$ of pear ester and $3 \mathrm{mg}$ of codlemone. Pherocon CM L2 (PH) was loaded with $3 \mathrm{mg}$ of codlemone. The acetic acid lures (AA) were prepared with $6 \mathrm{~mL}$ glacial AA (99\%) (Sigma-Aldrich, St. Louis, MO, USA) added to a $8.0 \mathrm{~mL}$ polyethylene vial (Nalg-Nunc International, Rochester, NY, USA) with a 3.0 $\mathrm{mm}$ hole in the screw cap. A $10 \mathrm{~g}$ cotton ball was placed in each vial.

\section{Field experiment - Washington State (USA)}

A study was conducted in a 35-year-old block of 'Delicious' apples situated near Yakima, WA $\left(46.56^{\circ} \mathrm{N}, 120.39^{\circ} \mathrm{W}\right)$. The study was run from 3-17 August 2011. Forty traps were randomized, spaced $20 \mathrm{~m}$ apart, and hung on poles in the upper third of the canopy. The orchard was treated in May with 400 CideTrak CM dispensers loaded with 120 mg codlemone (Trécé Inc., Salinas, CA, USA). Four treatments with 10 replicates were established using orange and clear delta traps baited with separate PE lures and AA lures ( $\mathrm{PE}+\mathrm{AA})$ or single $\mathrm{PE}+\mathrm{PH}$ lures. Traps were checked and new liners were used midway through the experiment. Moths were counted and sexed in the field.

\section{Field experiments - Maule Region (Chile)}

Trap and lure combinations were evaluated in four abandoned apple orchards. Orchard 1 was a 15-year-old mixed block of 'Red Chief', 'Royal Gala' and 'Granny Smith' located in Colín (35 $27^{\prime} 56.02$ " S, 71 $\left.{ }^{\circ} 44^{\prime} 4.08^{\prime \prime} \mathrm{W}\right)$. Orchard 2 was a 15 -year-old 'Red King Oregon', 'Royal Gala', and 'Fuji' orchard located in Pencahue (35 $23^{\circ}$ ' 9.15' S, $\left.71^{\circ} 48^{\prime} 38.97^{\prime \prime} \mathrm{W}\right)$. Orchard 3 was a 17-year-old mixed block of 'Granny Smith' and 'Royal Gala' situated in Villa Alegre (35 $1^{\circ}$ ' 12.24' S, $71^{\circ} 14^{\prime}$ $\left.26.18^{\prime \prime} \mathrm{W}\right)$. Orchard 4 was a 16 -year-old mixed block of 'Fuji' and 'Royal Gala' situated in Talca

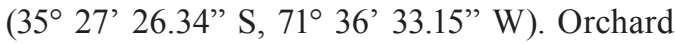


3 was removed after the 2009-2010 season and replaced for the 2010-2011 season by a 18-year-old mixed block of 'Red King Oregon', 'Royal Gala', and 'Granny Smith' in Rauco (34'55' 54.80' S, $\left.71^{\circ} 16^{\prime} 36.40^{\prime \prime} \mathrm{W}\right)$. The same set of trap and lure combination treatments was evaluated at each orchard, with the exception of the orange trap baited with $\mathrm{PE}+\mathrm{PH}$, which was not included in orchard 4 during the 2009-2010 season. Three or four traps for each treatment were randomly placed in a $30 \times 30 \mathrm{~m}$ grid in each apple orchard. In the first year of the study, traps were installed on 7 September 2009, and the study was run until 25 February 2010. Traps were installed for the second season on 21 September 2010 and checked until 15 March 2011. Traps were checked two or three times per week and rotated on each sampling date. Lures were replaced every eight weeks, liners as needed, and the AA vial every four weeks. All traps were placed in the upper third of the apple tree canopy (approximately $3 \mathrm{~m}$ high). Moths were removed from the traps on each date and sexed in the field using a magnifying glass.

\section{Statistical analyses}

Codling moth trap catch data were recorded as the number of individuals caught per day per trap. In the Washington study, a two-way experimental design with trap color (clear or orange) and lure $(\mathrm{PE}+\mathrm{AA}$ or $\mathrm{PE}+\mathrm{PH})$ as the independent variables was used. Separate analyses were performed for female and total trap catches as dependent variables. Analyses of the data from Chile compared the performance of the best trap-lure combination tested in Washington (Clear / PE+AA) with the trap-lure combinations used as the standard by growers in Chile (White / PH) and in Washington (Orange / PE $+\mathrm{PH}$ ). The experiment in Chile was run over two seasons (2009-2010 and 2010-2011) and two codling moth flights (first and second) for each season. Thus, a three-way design with trap-lure combination, season, and generation was used for this analysis. Separate analyses were performed for female and total trap catches as dependent variables. The codling moth flight periods were estimated from a logistic phenological model (Knight, 2007b). The first flight was considered from biofix (first sustained moth catch) to 444 cumulative degree days (lower threshold = $10^{\circ} \mathrm{C}$ ), whereas the second flight was considered from 445 degree days until harvest. Data were $\log (\mathrm{x}+1)$ transformed prior to an analysis of variance (ANOVA). Mean comparisons in significant ANOVAs were performed with a Duncan's test to allow better separation of means (Sokal and Rohlf, 1995) because our experiments had few treatments and the magnitude of the difference between means was small in female catches (Atil and Unver, 2001).

\section{Results}

\section{Field experiment - Washington State (USA)}

Significant differences in the mean catches of female and total moths were found for both trap and lure types in this study (Table 1). The mean catch of females $\left(\mathrm{F}_{1,36}=13.7, \mathrm{P} \leq 0.001\right)$ and total moths $\left(\mathrm{F}_{1,36}=4.0, \mathrm{P} \leq 0.05\right)$ differed significantly between clear and orange traps. The mean catch of females $\left(\mathrm{F}_{1,36}=30.6, \mathrm{P} \leq 0.001\right)$, but not total moths $\left(\mathrm{F}_{1,36}=2.2, \mathrm{P}=0.14\right)$, was significantly different between lures. The trap-lure interaction was not significant for either female or total moths. The PE $+\mathrm{AA}$ lure caught significantly more female moths than the $\mathrm{PE}+\mathrm{PH}$ lure with both trap types (Table 1). Both lure types placed in a clear trap caught significantly more female moths than the orange delta baited with $\mathrm{PE}+\mathrm{PH}$. The clear delta baited with PE+AA caught nearly 10 -fold more female moths per day than the orange delta baited with $\mathrm{PE}+\mathrm{PH}$. The total moth catches did not differ between lures within each trap type. However, the clear trap baited with $\mathrm{PE}+\mathrm{PH}$ caught significantly more moths than the orange delta baited with PE+AA, with a nearly 2-fold difference (Table 1). 
Table 1. Mean \pm SE moth catch per day for clear and orange delta traps baited with either pear ester (PE) and acetic acid (AA) or PE plus codlemone (PH), August 2011, Washington State.

\begin{tabular}{llcc}
\hline & & \multicolumn{2}{c}{ Mean \pm SE catch per day ${ }^{1,2}$} \\
\cline { 3 - 4 } Trap & Lure & Female moths & Total moths \\
\hline Clear delta & PE + AA & $0.38 \pm 0.06 \mathrm{a}$ & $0.59 \pm 0.12 \mathrm{ab}$ \\
Clear delta & PE + PH & $0.15 \pm 0.02 \mathrm{~b}$ & $0.84 \pm 0.27 \mathrm{a}$ \\
Orange delta & PE + AA & $0.24 \pm 0.04 \mathrm{ab}$ & $0.43 \pm 0.09 \mathrm{~b}$ \\
Orange delta & PE + PH & $0.04 \pm 0.03 \mathrm{c}$ & $0.81 \pm 0.20 \mathrm{ab}$ \\
\hline
\end{tabular}

${ }^{1}$ Column means followed by a different letter were significantly different, $\mathrm{P} \leq 0.05$, Duncan's test.

${ }^{2}$ Sample size $\mathrm{N}=10$.

\section{Field experiments - Maule Region (Chile)}

Significantly higher female catches were found in the clear traps baited with $\mathrm{PE}+\mathrm{AA}$ than in the orange traps baited with $\mathrm{PE}+\mathrm{PH}$ when pooled over the two flight periods $\left(\mathrm{F}_{1,22}=6.2, \mathrm{P} \leq 0.05\right)$, and higher female catches were found in the second than in the first generation overall $\left(\mathrm{F}_{1,22}\right.$ $=5.5, \mathrm{P} \leq 0.02)$. No significant effects on female catches were found for the season or any interaction with trap type. Significant differences were found in total moth catches between trap-lure combinations $\left(\mathrm{F}_{2,34}=32.2, \mathrm{P} \leq 0.001\right)$, while the effects of season and codling moth flight were not significant. Significant interactions were found between trap lure combinations and season $\left(\mathrm{F}_{2}\right.$, $\left.{ }_{34}=5.5, \mathrm{P} \leq 0.05\right)$ and test season and flight $\left(\mathrm{F}_{1,34}\right.$ $=5.1, \mathrm{P} \leq 0.05)$ but not between trap-lure combinations and moth flight. Multiple comparisons indicated that regardless of moth flight during the 2009-2010 season, total catches were higher in the orange traps baited with $\mathrm{PE}+\mathrm{PH}$ than in the clear trap baited with PE+AA (Table 2). The orange traps baited with $\mathrm{PE}+\mathrm{PH}$ showed higher total catches than the white traps baited with $\mathrm{PH}$ for the second but not the first codling moth flight of the 2009-2010 season (Table 2). Similarly, higher total catches were found in the 2010-2011 season for both the orange trap baited with $\mathrm{PE}+\mathrm{PH}$ and the white trap baited with $\mathrm{PH}$ compared with catches by the clear trap baited with $\mathrm{PE}+\mathrm{AA}$ in both codling moth flights (Table 2).

Table 2. Seasonal comparison of mean \pm SE moth catch per day for clear, orange, and white traps baited with either pear ester (PE) and acetic acid (AA) or PE plus codlemone (PH), 2009-2010 and 2010-2011, Maule Region.

\begin{tabular}{|c|c|c|c|c|c|}
\hline \multirow[b]{2}{*}{ Season (dates) } & \multirow[b]{2}{*}{ Trap / lure } & \multicolumn{2}{|c|}{$\begin{array}{c}\text { Mean } \pm \text { SE catch per day } \\
\text { Female }^{1,2}\end{array}$} & \multicolumn{2}{|c|}{$\begin{array}{c}\text { Mean } \pm \text { SE catch per day } \\
\text { Total }^{1,2}\end{array}$} \\
\hline & & First flight & Second flight & First flight & Second flight \\
\hline $2009-2010$ & Clear delta / PE $+\mathrm{AA}$ & $0.07 \pm 0.04$ & $0.30 \pm 0.19$ & $0.21 \pm 0.10 \mathrm{e}$ & $0.96 \pm 0.48 \mathrm{cde}$ \\
\hline \multirow[t]{2}{*}{ (7 Sep. - 25 Feb.) } & Orange delta / $\mathrm{PE}+\mathrm{PH}$ & $0.09 \pm 0.08$ & $0.15 \pm 0.14$ & $1.74 \pm 0.81 \mathrm{abc}$ & $3.39 \pm 2.14 \mathrm{a}$ \\
\hline & White diamond / PH & - & - & $0.89 \pm 0.35 \mathrm{cde}$ & $1.23 \pm 0.36 \mathrm{bcd}$ \\
\hline $2010-2011$ & Clear delta / $\mathrm{PE}+\mathrm{AA}$ & $0.16 \pm 0.10$ & $0.22 \pm 0.13$ & $0.35 \pm 0.15 \mathrm{e}$ & $0.50 \pm 0.34 \mathrm{de}$ \\
\hline \multirow[t]{3}{*}{ (21 Sep. - 15 Mar.) } & Orange delta / $\mathrm{PE}+\mathrm{PH}$ & $0.04 \pm 0.03$ & $0.05 \pm 0.05$ & $2.62 \pm 1.24 \mathrm{ab}$ & $2.31 \pm 1.41 \mathrm{ab}$ \\
\hline & White delta / PH & - & - & $2.71 \pm 0.49 \mathrm{a}$ & $2.50 \pm 1.31 \mathrm{ab}$ \\
\hline & & \multicolumn{2}{|c|}{ Both flights } & \multicolumn{2}{|c|}{ Both flights } \\
\hline \multirow[t]{3}{*}{ Both seasons } & Clear delta / PE $+\mathrm{AA}$ & \multicolumn{2}{|c|}{$0.19 \pm 0.05 \mathrm{a}$} & \multicolumn{2}{|c|}{$0.51 \pm 0.16 \mathrm{~b}$} \\
\hline & Orange delta / $\mathrm{PE}+\mathrm{PH}$ & \multicolumn{2}{|c|}{$0.08 \pm 0.03 \mathrm{~b}$} & \multicolumn{2}{|c|}{$2.52 \pm 0.35 \mathrm{a}$} \\
\hline & White diamond - delta / $\mathrm{PH}$ & \multicolumn{2}{|c|}{-} & \multicolumn{2}{|c|}{$1.83 \pm 0.45 \mathrm{a}$} \\
\hline
\end{tabular}

${ }^{1}$ Means between columns and rows followed by a different letter were significantly different, $\mathrm{P} \leq 0.05$, according to Duncan's test. ${ }^{2}$ Sample size $\mathrm{N}=4$. 


\section{Discussion}

In both the experiments performed in Washington State and the Maule Region, we found that clear delta traps baited with $\mathrm{PE}+\mathrm{AA}$ caught significantly more female codling moth than orange delta traps with PE+PH. In the Washington experiment, it is possible to attribute this result to the $\mathrm{PE}+\mathrm{AA}$ lure because orange traps baited with $\mathrm{PE}+\mathrm{AA}$ and similarly baited clear traps caught equal numbers of females. In previous studies in the United States, clear delta traps baited with $\mathrm{PE}+\mathrm{AA}$ were shown to catch higher numbers of codling moth females than orange delta traps baited with $\mathrm{PE}+\mathrm{PH}$ in experiments performed in MD-treated orchards (Knight, 2010b) and in poorly managed apple orchards (Knight, 2010a) in Washington.

Higher codling moth catches in PE baited traps have been reported to occur early but not later in the season in several studies (Light et al., 2001; Ioratti et al., 2003; Knight and Light, 2005a; b; Trimble and El-Sayed, 2005; Mitchel et al., 2008; but see Fernández et al., 2010). This effect may be related to a seasonal change in the competitive attraction of codling moth females toward ripening fruit (Knight and Light, 2005d). Our full-season experiments performed in Maule Region showed the opposite results, with significantly higher female catches during the second codling moth flight for both seasons. Although volatile compounds from fruit in the orchards most likely influence PE attraction for codling moth in the field (Light et al., 2001; Il'ìchev, 2004; Knight and Light, 2005b; Landolt and Guédot, 2008), our higher female trap catches in the second flight could be explained by the absence of codling moth control in the apple orchards used in our Maule Region studies. At these sites, a large proportion of the fruit (approximately 70\% for the four studied orchards) was injured by codling moth during the first generation and fell from the tree during the latter half of the season. Thus, the remaining low fruit density may have had a lower competitive attraction relative to the traps. The relative competitive attraction of the fruits remaining on the tree, most of which were injured by codling moth, is unclear. Some laboratory studies have found that injured fruit are more attractive than uninjured fruit (Reed and Landolt, 2002; Hern and Dorn, 2002), whereas other field studies have found no significant difference in attraction toward injured or uninjured fruit (Landolt and Guédot, 2008) or have shown higher female catches in PE-baited traps located near injured fruit clusters (Knight and Light, 2005b).

Our results also indicated that orange traps baited with $\mathrm{PE}+\mathrm{PH}$ lures showed higher total trap catches than clear traps baited with $\mathrm{PE}+\mathrm{AA}$ in all experiments from Maule Region but not in the experiment in Washington State. Because the latter experiment was performed in an apple orchard under $\mathrm{MD}$, it is unsurprising that the attraction of males to PH was most likely reduced. Similar results have been found in other studies performed in orchards with or without MD in Washington, where higher male catches obtained in traps baited with PH have been explained by the significant increase in total catches (Knight, 2010a; b). Higher total trap catches in orange traps baited with $\mathrm{PE}+\mathrm{PH}$ relative to white traps with $\mathrm{PH}$ lures were found only for the second generation during the 2009-2010 season in Chile. This result could be explained by the smaller size of the diamond white traps (Pherocon IIB) relative to the delta orange traps (Pherocon VI) that we used in the 2009-2010 season (Table 1). Our data with delta traps of the same size (Pherocon VI) from the 2010-2011 season do not support this previous result. Many studies have shown that different traps baited with $\mathrm{PE}+\mathrm{PH}$ lures increase male and total codling moth catches relative to traps baited with PH lures alone in orchards subjected to MD (Il'ìchev, 2004; Knight et al., 2005; Knight, 2010a; Fernández et al., 2010). In our abandoned orchard, the traps baited with PH alone or with the PE+PH blend mainly attracted codling moth males, but there was no evidence of a significant enhancement effect of PE on the PH attraction. In addition, the use of orange delta traps has shown an increase in total codling moth 
catches in Washington relative to white traps using either $\mathrm{PH}$ or $\mathrm{PE}+\mathrm{PH}$ lures (Knight and Fisher, 2006). However, neither the PE enhancement effect on $\mathrm{PH}$ attraction nor the orange trap color produced an increase in catches in the present study if traps of the same size were used. This result has also been found in other studies in orchards not subjected to $\mathrm{MD}$, and potential interference between $\mathrm{PE}$ and $\mathrm{PH}$ has been proposed as an explanation (De Cristofaro et al., 2004; Il'ìchev, 2004; Trimble and El-Sayed, 2005; Knight et al., 2005; Mitchell et al., 2008).

New lures based on semiochemical combinations using $\mathrm{PH}, \mathrm{PE}$ and AA have shown the potential value of future research aimed at identifying their interactive or synergic effects in combination with visual cues such as trap color and shape. Our results showed a higher attraction of female codling moth to clear traps baited with $\mathrm{PE}+\mathrm{AA}$ lures than to orange traps baited with $\mathrm{PE}+\mathrm{PH}$ in Washington (10-fold increase) and Maule (2fold increase pooled overall). Further studies in managed apple orchards, with or without MD, to compare codling moth populations from different regions should further improve our ability to increase the catch of codling moth females. This information will allow better tracking of the seasonal population dynamics of female codling moth and, therefore, more precise estimation and timing of insecticide sprays to control this pest.

\section{Acknowledgments}

This work was funded by Fondo de Desarrollo Científico y Tecnológico (FONDECYT) grant 1071029 to EFC. Doctoral fellowships to EB and WB from Universidad de Talca are also acknowledged. Helpful comments were provided by Richard Hilton (Oregon State University, Southern Oregon Research \& Extension Center, Medford, OR) and Douglas M. Light (USDA-ARS, Western Regional Research Center, Albany, CA). Felipe Van Diejen kindly provided access to his apple orchard in Talca.

\section{Resumen}

W. Barros-Parada, A.L. Knight, E. Basoalto y E. Fuentes-Contreras. 2013. Evaluación de trampas naranjas y transparentes con éster de pera para monitorear la polilla de la manzana (Lepidoptera: Tortricidae) en huertos de manzano. Cien. Inv. Agr. 40(2):307-315. Se realizaron estudios para evaluar el uso de varias combinaciones entre trampas y cebos para el monitoreo de la polilla de la manzana, Cydia pomonella (L.) (Lepidoptera: Tortricidae), en manzano Malus domestica Bordk. Los tratamientos incluyeron el uso de trampas transparentes, naranjas y blancas cebadas con uno o más de los siguientes atrayentes: $(E, E)$ 8,10-dodecadien-1-ol (codlemona, $\mathrm{PH}$ ), el compuesto mayoritario de la feromona sexual de la polilla de la manzana; $(E, Z)$-2,4-decadienoato de etilo (éster de pera, $\mathrm{PE}$ ), un compuesto volátil constituyente del olor a pera madura; y ácido acético (AA). Los estudios fueron conducidos en un huerto tratados con dispensadores de confusión sexual en el Estado de Washington (EE.UU.) y en cuatro huertos no tratados en la Región del Maule (Chile). En el Estado de Washington los cebos $\mathrm{PE}+\mathrm{AA}$ capturaron significativamente más polillas hembras que los cebos $\mathrm{PE}+\mathrm{PH}$, tanto en las trampas transparentes y naranjas. La trampa transparente capturó más polillas hembras que la trampa naranja con $\mathrm{PE}+\mathrm{PH}$. La captura total de polillas no se diferenció entre ambos cebos con distintos tipos de trampa. Las trampas delta transparentes, cebadas con $\mathrm{PE}+\mathrm{PH}$, capturaron más polillas totales que las trampas naranjas cebadas con PE+AA. En Chile, la trampa transparente cebada con $\mathrm{PE}+\mathrm{AA}$ capturó significativamente más hembras que la trampa naranja cebada con $\mathrm{PE}+\mathrm{PH}$, considerando ambos vuelos y temporadas de estudio. En tres de cuatro periodos de vuelo las trampas blancas, cebadas con feromona, capturaron un número 
similar de polillas totales que las trampas naranjas cebadas con PE $+\mathrm{PH}$. En dos de los cuatro periodos de vuelo las trampas transparentes con $\mathrm{PE}+\mathrm{AA}$ capturaron significativamente menos polillas totales que los tratamientos que incluyeron cebos con PH. Estos datos sugieren que la adopción de trampas delta transparentes con cebos de PE+AA permitiría a los productores un mejor seguimiento estacional de la dinámica poblacional de las hembras de la polilla de la manzana.

Palabras clave: Codlemone, Cydia pomonella, cebos, monitoreo, ester de pera, semioquímicos.

\section{References}

Atil, H., and Y. Unver. 2001. Multiple comparisons. OnLine J. Biol. Sci. 1: 723-727.

Barnes, M.M. 1991. Codling moth occurrence, host race formation, and damage. In: Van der Geest, L.P.S. and H.H. Evenhuis (eds.). Tortricid pests: their biology, natural enemies, and control. Elsevier, Amsterdam. p. 313-327.

De Cristofaro, A., C. Ioriatti, E. Pasqualini, G. Anfora, G.S. Germinara, M. Villa, and G. Rotundo. 2004. Electrophysiological responses of Cydia pomonella to codlemone and pear ester ethyl (E,Z)-2,4-decadienoate: peripheral interactions in their perception and evidences for cells responding to both compounds. Bull. Insectol. 57:137-144.

Fernández, D., E.L. Cichón, S. Garrido, M. RibesDasi, and J. Avilla. 2010. Comparison of lures loaded with codlemone and pear ester for capturing codling moths, Cydia pomonella, in apple and pear orchards using mating disruption. J. Insect Sci. 10:139.

Hern, A., and S. Dorn. 2002. Induction of volatile emissions from ripening apple fruits infested with Cydia pomonella and the attraction of adult females. Entomol. Exp. Appl. 102:145-151.

Il'ìchev, A.L. 2004. First Australian trials of ethyl (2E, 4Z)-2,4-decadienoate for monitoring of female and male codling moth Cydia pomonella (L.) (Lepidoptera: Tortricidae) in pome fruit orchards. Gen. Appl. Entomol. 33:15-20.

Ioriatti, C. F. Molinari, E. Pasqualini, A. De Cristofaro, S. Schmidt, and I. Espinha. 2003. The plant volatile attractant (E,Z)-2,4-ethyl-decadienoate (DA2313) for codling moth monitoring. Boll. Zool. Agr. Bachic. 35:127-137.

Knight, A.L. 2007a. Influence of within-orchard trap placement on catch of codling moth (Lepidoptera: Tortricidae) in sex pheromone-treated orchards. Environ. Entomol. 36:425-432.

Knight, A.L. 2007b. Adjusting the phenology model of codling moth (Lepidoptera: Tortricidae) in Washington state apple orchards. Environ. Entomol. 36:1485-1493.

Knight, A.L. 2010a. Increased catch of female codling moth (Lepidoptera: Tortricidae) in kairomone-baited clear delta traps. Environ. Entomol. 39:583-590.

Knight, A.L. 2010b. Improved monitoring of female codling moth (Lepidoptera: Tortricidae) with pear ester plus acetic acid in sex pheromonetreated orchards. Environ. Entomol. 39:12831290.

Knight, A.L., and E. Milczky. 2003. Influence of trap color on the capture of codling moth (Lepidoptera: Tortricidae), honeybees, and non-target flies. J. Entomol. Soc. Brit. Columbia 100:65-70.

Knight, A.L., and D.M. Light. 2005a. Timing of egg hatch by early-season codling moth (Lepidoptera: Tortricidae) predicted by moth catch in pear ester- and codlemone-baited traps. Can. Entomol. 137:728-738.

Knight, A.L., and D.M. Light. 2005b. Developing action thresholds for codling moth (Lepidoptera: Tortricidae) with pear ester and codlemonebaited traps in apple orchards treated with sex pheromone mating disruption. Can. Entomol. 137:739-747. 
Knight, A.L., and D.M. Light. 2005c. Seasonal flight patterns of codling moth (Lepidoptera: Tortricidae) monitored with pear ester and codlemonebaited traps in sex pheromone-treated apple orchards. Environ. Entomol. 34:1028-1035.

Knight, A.L., and D.M. Light. 2005d. Factors affecting the differential capture of male and female codling moth (Lepidoptera: Tortricidae) in traps baited with ethyl (E,Z)-2,4-decadienoate. Environ. Entomol. 34:1161-1169.

Knight, A.L., and J. Fisher. 2006. Increased catch of codling moth (Lepidoptera: Tortricidae) in semiochemicals-baited orange plastic delta-shaped traps. Environ. Entomol. 35:1597-1602.

Knight, A.L., R. Hilton, and D.M. Light. 2005. Monitoring codling moth (Lepidoptera: Tortricidae) in apples with blends of ethyl (E,Z)-2,4decadienoate and codlemone. Environ. Entomol. 34:598-603.

Knight, A.L., L. Hawkins, K. McNamara, and R. Hilton. 2009. Monitoring and managing codling moth clearly and precisely. Good Fruit Grower 60(5):26-27.

Knight, A.L., D.M. Light, and R.M. Trimble. 2011. Identifying (E)-4,8-dimethyl-1,3,7 nonatriene plus acetic acid as a new lure for male and female codling moth (Lepidoptera: Tortricidae). Environ. Entomol. 40:420-430.

Kutinokova, H., M. Subchev, D.M. Light, and B. Lingren. 2005. Interactive effects of ethyl (2E, 4Z)-2, 4-decadienoate and sex pheromone lures to codling moth: apple orchard investigations in Bulgaria. J. Plant. Prot. Res. 45:49-53.

Landolt, P.J., D.M. Suckling, and G.J.R. Judd. 2007. Positive interaction of a feeding attractant and a host kairomone for trapping the codling moth, Cydia pomonella. J. Chem. Ecol. 33:2236-2244.

Landolt, P.J., and C. Guédot. 2008. Field attraction of codling moths (Lepidoptera: Tortricidae) to apple and pear fruit, and quantitation of kairomones from attractive fruit. Ann. Entomol. Soc. Am. 101:675-681.

Light, D.M., A.L. Knight, C.A. Henrick, D. Rajapaska, B. Lingren, J.C. Dickens, K.M. Reyn- olds, R.G. Buttery, G. Merrill, J. Roitman, and B.C. Campbell. 2001. A pear-derived kairomone with pheromonal potency that attracts male and female codling moth, Cydia pomonella (L.). Naturwissenschaften 88:333-338.

Mitchell, V.J., L.A. Manning, L. Cole, D.M. Suckling, and A.M. El-Sayed. 2008. Efficacy of the pear ester as a monitoring tool for codling moth Cydia pomonella (Lepidoptera: Tortricidae) in New Zealand apple orchards. Pest Manag. Sci. 64:209-214.

Reed, H.C., and P.J. Landolt. 2002. Attraction of mated female codling moths (Lepidoptera: Tortricidae) to apples and apple odor in a flight tunnel. Fla. Entomol. 85:324-329.

Sauphanor, B., P. Franck, T. Lasnier, J.-F. Toubon, D. Beslay, T. Boivin, J.-C. Bouvier, and M. Renou. 2007. Insecticide resistance may enhance the response to a host-plant volatile kairomone for the codling moth, Cydia pomonella (L.). Naturwissenschaften 94:449-458.

Sokal, R.R., and F.J. Rohlf. 1995. Biometry: the principles and practice of statistics in biological research. W.H. Freeman, New York, USA. 937 pp.

Trimble, R.M., and A.M. El-Sayed. 2005. Potential of ethyl (2E, 4Z)-2, 4-decadienoate for monitoring activity of codling moth (Lepidoptera: Tortricidae) in eastern North American apple orchards. Can. Entomol. 137: 110-116.

Thwaite, W.G., A.M. Mooney, M.A. Eslick, and H.L. Nichol. 2004. Evaluating pear-derived kairomone lures for monitoring Cydia pomonella (L.) (Lepidoptera: Tortricidae) in Granny Smith apples under mating disruption. Gen. Appl. Entomol. 33:56-60.

Vickers, R.A., and G.H.L. Rothschild. 1991. Use of sex pheromones for control of codling moth. In: Van der Geest, L.P.S., and H.H. Evenhuis (eds.). Tortricid pests: their biology, natural enemies and control. Elsevier, Amsterdam, The Netherlands. p. 339-354.

Witzgall, P., L. Stelinski, L. Gut, and D. Thomson. 2008. Codling moth management and chemical ecology. Annu. Rev. Entomol. 53:503-522. 
